\title{
COMPACT CITY CONCEPT FROM THE VIEWPOINT OF PLACE-MAKING
}

\author{
ZULAL NURDAN KORUR \\ Department of Architecture, Istanbul Medipol University, Turkey
}

\begin{abstract}
Today, with the rapid increase of urban populations, consequently increasing the urban service units, the efforts to maintain sustainable principles without compromising the quality of urban life has become one of the most important problems in the city. Sustainable cities are places where the environment is least polluted, resources are used effectively and efficiently, buildings are obliged to rise vertically instead of growing horizontally, urban mobility is minimized, but spatial designs are realized where the concept of acquisition is highlighted. In recent years, compact urban theories have been introduced that can be answered. The fact that urban planning has been done does not always mean that there are liveable places. It can be defined as the places that allow limited spaces, high density, mixed use and less energy consumption in compact cities. In this article, the aim is to discuss the definition of compact city, the risks of compact city, the change of urban identity, the loss of sense of belonging, the concepts of "planned" and "unplanned" accompanying urban planning. Within the framework of the importance of compact city, sustainable city, sustainable development quality of life, it was realized by examining an unapplied project proposed for Western Kowloon vertical park and water culture centre.

Keywords: compact city, sustainable city, sustainable development, place-making.
\end{abstract}

\section{INTRODUCTION}

Compact city is a quite new concept. In planning literature from 1990 onwards interested on the concept of compact city which has been designed to ensure sustainable development within the urban environment and to counteract the negative social issues, economic dimensions and environmental impacts of urban sprawl. There have written many scientific paper to define exactly what a compact city is, “... but in general [it] is taken to mean a relatively high-density, mixed-use city, based on an efficient public transport system and dimensions that encourage walking and cycling" [1].

Compact city is a dense and socially diverse city where economic and social activities overlap and communities gather around neighbourhoods [2]. Sustainable city is not only about environmental issues, but also about economic compatibility, social equality and liveability. The strong relationship between urban form and sustainability suggests that the shape and density of cities may have some positive and negative effects for their future.

In the past decade, city planners, architects and politicians have been committed to designing more compact cities to achieve an increasingly sustainable urban form. Urban compression policies are:

- urban regeneration;

- mixed-use buildings;

- re-planning of town centres;

- rural areas development;

- $\quad$ high density urban pattern;

- improvement of public transport; and

- intensification of urban development in the public transport network.

The compact city is designed to use land resources and infrastructure more efficiently and to reduce car use as public transport becomes more preferable at high urban densities. In 
addition, many of the compact cities are observed to have many differences compared to other compact cities in the world. This leads to the introduction of a compact city model based on questioning accuracy feasibility and acceptability. The theory of accuracy, feasibility and admissibility, which Breheny [3] suggested that the compression case put forward to be subjected to three types of tests, played an important role in the literature. While the conclusion of reality is not whether it provides environmental benefits when it comes to compression, it has received much attention.

The compact city can potentially achieve more than just saving land through development; it can also address some wider issues of sustainability. However, this also means that these wider claims of sustainability such as improvement in the quality of life can be questioned on many different levels. The foreseen benefits of the compact city model have been growing steadily; the concrete empirical evidence which supports these claims loses its validity.

In literature, three features of the compact city are identified: high-density, mixed-use and intensity [1]. High-density and mixed-use are related to the form of the compact city while the intensity focuses on the process of urban compaction. While density, one of these three features, focuses on the urban compression process, high density and mixed-use features are related to the shape of the compact city. This third feature intensity is critical in that there are just a few opportunities for a compact city to be recreated, which in any case would appear highly contradictory given the aims of urban compaction. This third feature intensity is critical in that there are just a few opportunities for a compact city to be recreated, which in any case would appear highly contradictory considered the aims of urban compaction. Thus, "...more compact cities can only be achieved through a process of making existing cities denser, of encouraging more people to live in urban areas and of building at higher densities: of intensifying cities" [4].

Compact city policies have mostly been organized primarily to reduce the use of private cars and to minimize the loss of countryside. However, theorists who put forward of the concept argue that more than just environmental benefits could be gained by intensifying urban areas; in fact "higher density settlements are claimed to be more socially sustainable because local facilities and services can be maintained, due to high population densities, and therefore access to goods and services is more equitably distributed" [4]. Furthermore, "...high-density urban living is seen as a prerequisite for vitality, vibrancy, cultural activities and social interaction" [4]. Therefore, theoretically, it appears that a solution to the sustainable city problem was discovered in planning literature by the mid-1990s. The controversy over the exact definition of a compact city and what a great variety of urban forms have been promoted as "compact" has increased substantially throughout the literature on urban sustainability over the past twenty years. While some efficiency regarding the provision of services could be gained through exponential growth of population density, the complexity of the whole compact city concept shows us that in many cases no direct relationship between economic growth and intensification can be found. Improvements on social equity through the compact city model depends on these aforementioned factors. Reduction in the dwelling sizes due to increased urban density, health risks directly related to the residential areas density or proximity of residential areas to the industrial areas in "mixed-use" models, higher crime rates related to the high-density living, the potentially negative impact of it on social segregation and high housing prices are all the undesirable social outcomes of the compact city model. According to Burton, in this model, "when looked at in its entirety - that is, as a combination of all the different indicators - social equity has a limited relationship with compactness" [1]. 


\section{SUSTAINABILITY-SUSTAINABLE CITY}

Stefan Behnisch [5] finds a sustainable city hard to define, but easy to understand from the viewpoint of an architectural approach. He has been experimenting "green architecture" since the 1970s. He has emphasized the creative environmental thinking inherent in European and North American Architecture. The American green design is relatively new when compared with the European, especially with the German green design. Behnisch's projects are centred around "human being", and express sustainability, a concept which he does not define.

According to Behnisch [5], a sustainable building carries some properties reshaped in line with location and geography where it's built, climate, cultural factors and geopolitical context. In urban planning, the aim should be the creation of the urban region. For sustainability, public spaces should be planned holistically. Behnisch believes in qualitative sustainability, in architects' responsibilities and in how greatly sustainability affects the social, political, and economic conditions of a society According to Behnisch, sustainable architecture is "content-driven architecture... not purely formal architecture" [5].

He uses glass and stone for a sustainable building. Because according to him, glass is both modern and feasible material and stone blended with it seems to be a way of balancing the solidity and transparency. He has carried out his works on rural earth using adaptable plants. His main aim has been the revitalization of the region.

His flexibly expanding and shrinking gardens and courts have become parts of his design in the 1990s. The Allston Campus has both sustainability and architectural quality.

Searching for a form to be used in sustainable structures will contribute to the integrity of any project. Such contribution may not be very expressive but aims to pave the way for an architectural approach "... .beyond aesthetic impact". Sustainability is directly related to such concepts as humanity, diversity, flexibility, safety, being more active, living more healthily, experiencing, being more inclusive, and invitational.

\section{COMPACT CITY AND SUSTAINABLE DEVELOPMENT}

After the publication of Our Common Future by the Brundtland Commission in 1987 [6], some factors such as the ever-increasing population and more importantly the almost rapid growth in the use of resources many of which are non-renewable have been processed in contradiction with desire to plan a more sustainable future [7].

Since the 1970s, the concept of sustainability has existed in the urban planning literature. However, although it was thought to be radical when it was proposed, "Our common future" [6], also known as the "Brundtland Report" published in 1987, made sustainability mainstream. Sustainable development principles are becoming increasingly important as the goal of creating an economic, social and environmentally better future for the world. Sustainability has been incorporated in urban planning theory, both through the promotion of a "compact city" model for urban growth rather than "unsustainable urban sprawl", and through a renewed focus on the importance of urban design, known as "New Urbanism" [7].

What makes it particularly difficult to find a solution to this problem is the complexity of the proposals towards creating a "compact city" or attaining "smart growth" and the wide variety of suggested "solutions" to the "urban sprawl problem". Also, there are many difficulties in finding an exact definition of the "compact city", and being able to determine what is, and what is not a "compact urban form". The higher density development along the public transport corridors or the creation of high-density "nodes" or sub-centres concentrating traffic flows are sufficient to encourage the provision of public transport.

However, it has further been claimed that the process of urban intensification is often of more important role for both acceptability and sustainability than absolute densities, and recent theoreticians on the compact city [8], [9] have tended to agree that "... the high-density 
buildings most appropriate for the compact city accepts traditional urban land-use patterns such as streets and squares and medium-rise or low-rise high-density housing. Because of these buildings, it is possible to provide each housing with its front door onto a public street and to provide gardens for all family housings" [8]. Thus, the "compact city" proved to be a highly complex concept not only related to an increase in density but also a variety of building forms of density across the urban landscape to obtain its "benefits".

There are four main principles essential for the transition from urban sprawl to a compact city model: strong supportive communities, a high-quality living environment, a region that is easy to get around, protection of the cost and surrounding natural environment. The urban form and sustainability relation is one of the most debated issues on the international environmental agenda. These cities form can have on resource depletion and social and economic sustainability, are central to this ongoing debate.

For Schoffham and Vale [10], "compact" refers more to the degree of autonomy a neighbourhood has than to its physical form. They support a decentralised urban form which is physically and "virtually" compact: In the light of current economic trends, environmental objectives, the current aspiration towards a life of high-quality and political reality; we could conclude that the compact city model is "unsuccessful, undesirable and unworkable". There is no doubt that a radical change in the form and function of the city will be required to meet any of these criteria for sustainability. Urban sprawl clashes with most, if not all, principles of sustainable development. Both Habitat Agenda and The UN's Agenda 21 say that urban sustainability goals should include: "a compact urban buildings; the preservation of open space and ecosystems; reduced car use; reduced pollution and waste and; the design of liveable and community-oriented environments; decent, affordable, and appropriately planned housing; improved opportunities and social equity for the least advantaged; and the development of a restorative local economy" [11].

For sustainability to be accomplished involved in future urban development programs, either these cultural attitudes should change immediately (which seems unlikely in the near future), or developments should be carefully planned to be more environmentally friendly and economically and socially sustainable, but at the same time appear to the users as attractive places to live.

In "Defining sustainable urban form" [12], Williams claim that "...until recently there was some consensus that compact urban forms provided the most sustainable future". Also, more recent research has led to important questions determining the complexity of the urban environment which may cause to urban intensification policies with consequences far removed from the goal of more sustainable cities [12]. He also propose that instead of reaching on one particular solution, there is a need to notice that a great diversity of urban features are likely to exist within a city and that urban compaction should only be seen as one way of achieving sustainable urban form. There is a strong relationship between urban form and sustainable development, but it is not simple and straightforward. It has been suggested that a sustainable city "must be of a form and scale appropriate for walking, cycling and efficient public transport, and compact enough to encourage social interaction" [7]. In existing cities, the concept of compaction is obtained through some processes that intensify development and encourage more people to revitalise them. The idea behind compact city model is an important step in the attempt to find sustainable urban forms.

\section{WEST KOWLOON VERTICAL PARK AND WATERFRONT CULTURAL CENTRE}

The West Kowloon Vertical Park and Waterfront Cultural Centre Project is a good example of Ken Yeang's sustainable approach to building design [13]. It is an extension of green 
building mainstream and as an innovative tool, he makes use of economies in high-rise buildings. To design with sustainability in mind is an unavoidable fact in the contemporary and future environment. This complex integration of the arts, cultural and entertainment zones in Hong Kong with heavy commercial, residential, institutional programs spreads on a large area of 40 hectares. The built form and landscape are synthesized in harmony. This Project exemplifies the "low-energy use", "eco-cells", "light shelves", "light pipes", "sky-courts", "vertical landscaping" characteristics of Yeang's architecture with the final aim of creating a protective eco-balance. The project's conceptual framework includes the following ideas:

- Recreation, cultural and retail integrated facilities will be enjoyed both by the inhabitants and the tourists.

- The pier towers overlook the water over the landscaped parks.

- The Project offers an ecological corridor as an environmentally more sustainable solution when it's compared to the idea of urban park.

- Old and proposed transportation networks are integrated.

- The programmatic spaces are provided with ventilation and natural lighting.

- "Green Jacket" is extended through roofs from the landscape to urban plazas for public use.

- The continuous park connecting different parts of the site and enables the integration of the site with the environment through suspension bridges.

- The user has easy access to such cultural facilities as landmark Opera House, Cultural Plaza, Amphitheatre, Mediateque and retail zones in the city.

- Within the scope of the continuous concourse project, some facilities on the scenic bridge, marina and some other amenities are designed.

- Form of the built landscape and marine environment is designed to be continuously linked with a central park and continue on the upper levels.

This vertical master-plan adds a residential area to the marina as the final phase of development and eco-bridge plans the rooftop ecological corridor in such a way to make it possible to walk through landscape and forest. Furthermore, it designs eco-cells for the vertical flow of natural ventilation and illuminates the lower building spaces, creates a stepped-form to maximize the view and designs the office and hotel pier towers in such a manner to connect the "green jacket" landscaped roof with the external facilities, parks and trails. In this way, it preserves local ecology and integrates the environmental demands and local sources. As Powell [14] has put it, “... This building addresses the challenge to enter the twenty-first century with a respect for nature but also with the technological response, using clean and efficient energy technologies" (Figs 1, 2 and 3).

\section{QUALITY AND THE COMPACT CITY}

The relationship between sustainability and the housing quality, as set by the World Commission on Environment and Development, is stated in its report of 1987. Accordingly, Urban Life Quality is associated with the residential experience, neighbourhood quality and the quality of the dwelling. Housing quality is actually an integral part of life quality [16].

As a result of the compact city policies implemented in developing countries, in the big cities, poor people concentrate in large densities and usually live on the outskirts of the city. In the inner city, they also crowd in. The mega-city policies must accommodate such growth and crowding [17]. The debate of achieving compact city is unlikely in such countries [18].

Compact city in the developed countries is more sustainable than it is in the developing countries, as Richardson et al. [19] claim that this question is not answerable in developing countries due to the lack of criteria for sustainability and reference point. 


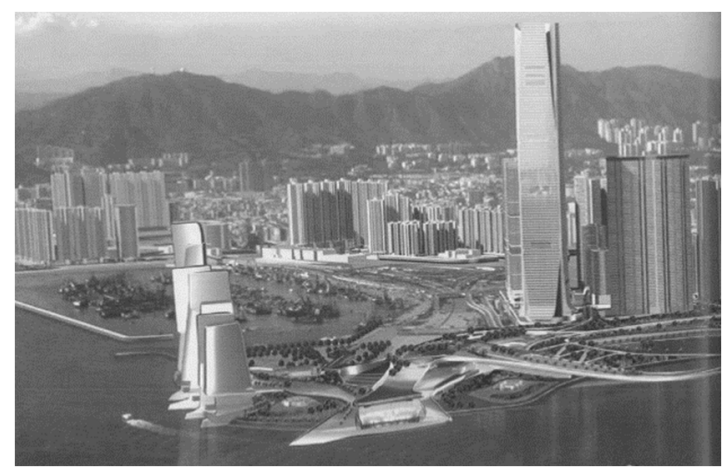

Figure 1: T.R. Hamzah and Yeang, Master Plan for West Kowloon Vertical Park and Waterfront Cultural Centre, Hong Kong [15, p. 58].

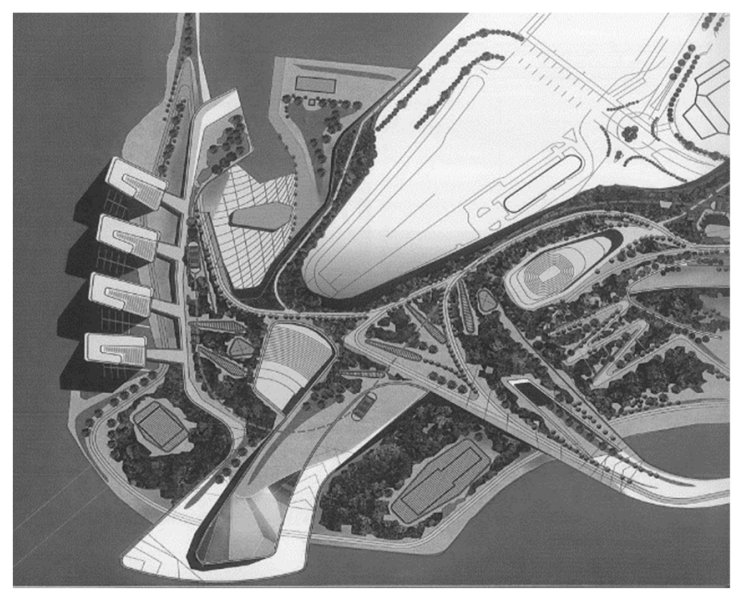

Figure 2: T.R. Hamzah and Yeang, Master Plan for West Kowloon Vertical Park and Waterfront Cultural Centre, Hong Kong [15, p. 56].

The economy inland consumption is obtained through more compactness at the metropolitan area level. Compactness in peripheral squatter settlements and inner-city slums usually signifies inadequate sanitation and water provision systems and general environmental degradation in the developing countries. In this sense, urban life quality has both subjective and objective dimensions.

Therefore, consideration of just physical attributes of the environment is insufficient to justify a full assessment of life quality. Social, psychological, and cultural characteristics of that environment must also be analysed. This is the best possible way to fulfil a sense of identity, safety, social status etc. in the urban context.

The relationship between the quality of life and the compact city model has usually been clarified through the factors of satisfaction and dissatisfaction in a post-industrial city. Quality of life and mobility within the city should not be identified as the expression of free choice over residential locations [20]. 


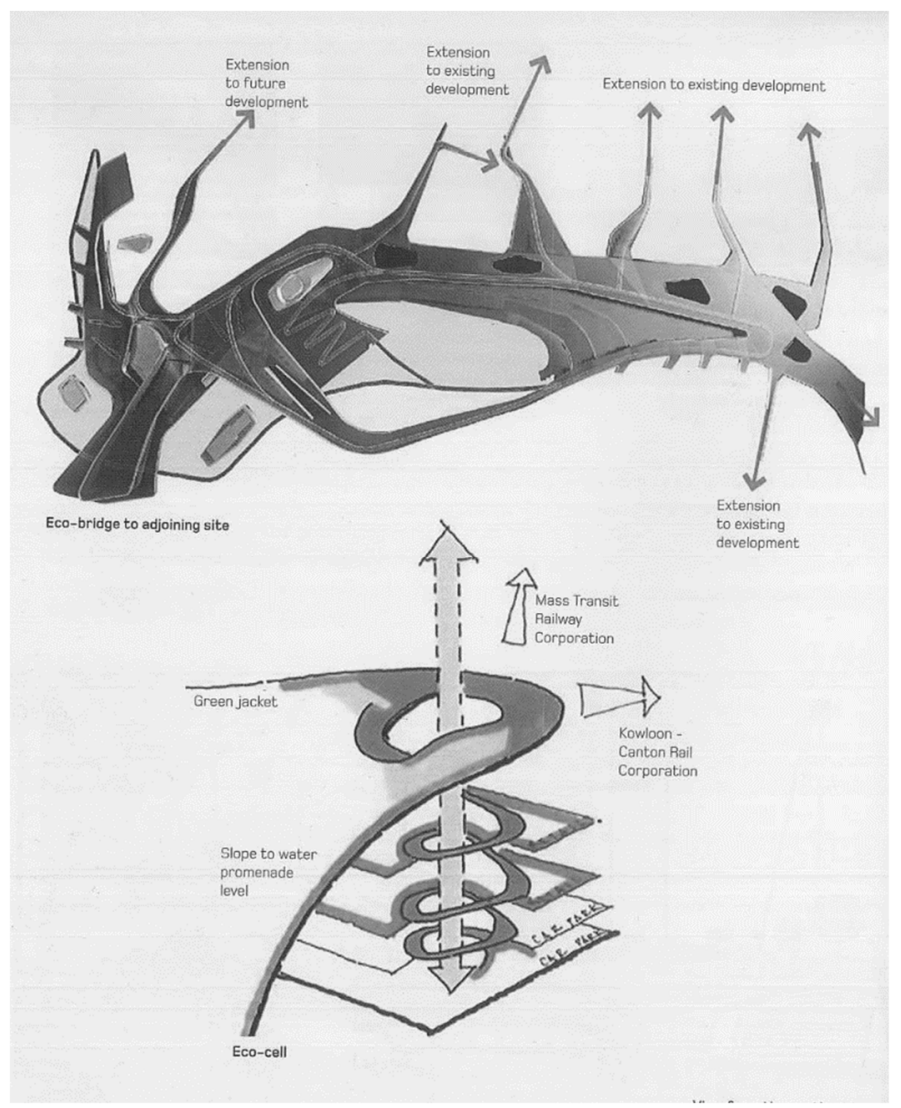

Figure 3: T.R. Hamzah and Yeang, Master Plan for West Kowloon Vertical Park and Waterfront Cultural Centre, Hong Kong [15, p. 62].

\section{SIGNIFICANCE OF PLACE-MAKING IN MEASURING LIFE QUALITY}

According to Lang [21], the place is directly relevant to the sense of belonging to a given built environment - which will be enhanced through memories and the myths of inhabitants. Different dimensions of quality in the process of designing and construction and use are general imageabilities, functionality, stability, aesthetical and environment.

"Architectural identity of urban milieu pieces together all tangible features of the urban environment with all the intangible ones which are the combination of the culture, tradition, social structure and the needs and functions of the architectural environment formed in time" [22]. Everyday life is important. Lefebvre's [23] description of daily life consists of these three elements: work, leisure and family life.

Quality of life is "...what makes a community or rural area memorable" [24]. In particular, transportation is a very significant aspect of life quality in daily life which makes it possible to access the offices, educational facilities, shopping centres and other facilities in a city. Following the most basic criterion of housing; access to the health and other social facilities is of capital importance. It required an affordable public transportation network [25].

Transportation is easier by motor vehicles in developed countries. Differently from the case in the developed countries, there is a large gap between the rich and the poor in the 
developing countries. While the poor cannot afford the motorized transport systems, the rich have no such a problem at all. People usually fall into the mistake of correlating density with the environmental quality variables. Although traffic congestion is worse in dense environments, the environmental quality reflects many considerations other than density such as industrial structure, climate, topography, types of policy instruments, water resources, institutions, regulations and enforcement rates [26]. According to Hardoy and Satterthwaite [27], high density is an advantage in that high population densities reduce the unit costs of infrastructure and services (i.e., garbage collection, infrastructure...). Density, therefore, is less important than crowding.

According to Heidegger, "the notion of identity is a fundamental one in 'Everyday Life"" [28]. He further argues that identity sticks on us, no matter where we are and to whatever we are related to. "There are as many identities of place as there are people", says Nairn [29]. The identity is reshaped in accordance with the individual perception and physical appearances of the cities. Components which make up places are static physical settings, activities, and meanings. These are the three basic elements which comprise the identity of places. The spirit of a place is preserved despite the possible subtle changes in a setting. "The identity of place takes many forms, but it is always the basis of our experience of this place as opposed to any other" and "the mass identity of place is a consensus identity that is remote from direct experience for it is provided more or less ready-made by the mass-media" [28].

\section{CONCLUSION}

As a conclusion, this paper emphasizes the role of the cities with their unchanging landmarks and the mission of the cities to establish an identity inside a territory. Thus place-making models are crucial to understand this process in which a vital public destination has been created. Compact city and sustainable city are the most crucial concepts which have to be clarified in order to understand the overall process. The compact city model has strong social power on the diversification of a city by arranging the social activities and facilities which are gathered around neighbourhoods. This social power is nourished with existing land resources and infrastructures which we can call possible alternatives to a sustainable environment. The compact city has the potential to address most of the wider issues of the sustainable city as a high-density, mixed-use, and as an intensified city. Thus, the term compact is not only related to an increase in density but also refers to the different forms of density which creates a transition from an urban sprawl to a compact city with a strong supportive community which has a high-quality living environment. This region should be easy to get around and should protect the monetary and surrounding natural resources. These basic issues show that a compact and sustainable city is not just related to the form of a compact structure. It should also be oriented by the policies of urban compaction, which involve a wide range of promotions. Thus, social, psychological, and cultural characteristics of that environment must also be analysed well so that the physical attributes of the environment could be adequate for justifying a full assessment of life quality.

\section{REFERENCES}

[1] Burton, E., The compact city: Just or just compact? Urban Studies, 37(11), pp. 19692001, 2000.

[2] Rogers, R. \& Gumuchdjian, P., Cities for Small Planet, Faber and Faber Limited: London, pp. 13-23, 1997.

[3] Breheny, M., Urban compaction: Feasible and acceptable?. Sustainable Urban Development, 14(4), pp. 209-217, 1997. 
[4] Williams, K., Burton, E. \& Jenks, M. (eds), Achieving the compact city through intensification: An acceptable option?. The Compact City: A Sustainable Urban Form? E \& FN Spoon: London, pp. 71-83, 1996.

[5] Mortice, Z., Stefan Behnisch plants the seed of a new campus at Harvard: The Allston Science Complex embraces sustainability beyond prescriptive habits. https://info.aia.org/aiarchitect/thisweek09/0327/0327d_behnisch.htm. Accessed on: 18 Jun. 2020.

[6] World Commission on Environment and Development, Our common future. Oxford University Press: Oxford, 1987.

[7] Elkin, T., McLaren, D. \& Hilmann, M., Reviving the City: Towards Sustainable Urban Development, Friends of the Earth: London, 1991.

[8] Burton, E., Measuring urban compactness in UK towns and cities. Environment and Planning B: Planning and Design, 29, pp. 219-250, 2002.

[9] Garcia, D. \& Riera, P., Expansion versus density in Barcelona: A valuation exercise. Urban Studies, 40(10): pp. 1925-1936, 2003.

[10] Scoffham, E. \& Vale, B., How compact is sustainable - how sustainable is compact?. The Compact City: A Sustainable Urban Form?, eds K. Williams, E. Burton \& M. Jenks, E \& FN Spoon: London, pp. 66-73, 1996.

[11] Wheeler, S., Planning for metropolitan sustainability. Journal of Planning Education and Research, 20, pp. 133-145, 2000.

[12] Williams, K., Burton, E. \& Jenks, M. (eds), Defining sustainable urban form. The Compact City: A Sustainable Urban Form?. E \& FN Spoon: London, pp. 7-9, 2000.

[13] Hart, S., Eco Architecture the Work of Ken Yeang, John Wiley \& Sons, Ltd: West Sussex, pp. 182-190, 2011.

[14] Powell, R., Rethinking the Skyscrapers: The Complete Architecture of Ken Yeang, Thames \& Hudson: London, p. 158, 1999.

[15] Yeang, K., Eco Master Planning, John Wiley \& Sons Ltd.: Sussex, 2009.

[16] Andrews, F.M., Population issues and social Indicators of well-being. Population and Environment, 6(4), pp. 210-230, 1983.

[17] Jones, T.L., Compact city policies for megacities: Core areas and metropolitan regions. The Compact Cities: Sustainable Urban Forms for Developing Countries, Spoon Press: London, pp. 37-52, 2000.

[18] Carmona, M., The regional dimension of the compact city debate: Latin America. The Compact Cities: Sustainable Urban Forms for Developing Countries, Spoon Press: London, pp. 53-62, 2000.

[19] Richardson, H.W., Christine Bae, C. \& Baxamusa, H., Compact cities in developing countries: assessment and implications. The Compact Cities: Sustainable Urban Forms for Developing Countries, Spoon Press: London, pp. 25-36, 2000.

[20] Relph, E., On the identity of places. Urban Design Reader, Elsevier: Amsterdam, pp. 103-107, 1976.

[21] Lang, J.T., Creating Architectural Theory: The Role of Behavioral Sciences in Environmental Design, Van Nostrand Reinhold: New York, 1987.

[22] Erem, Ö. \& Şener, S.M., Analysis of method for architectural identity of the streets. Quality of Urban Life: Policy versus Practice, ITU, Quality of Urban Life and Environmental Planning Research Centre: Istanbul, pp. 452-462, 2003.

[23] Lefebvre, H., Critique of Everyday Life: Foundations for a Sociology of the Everyday Life, Verso: London, 2002.

[24] Berkshire Planning, Berkshire Regional Planning Commission, Quality of life and transportation fact sheet. www.berkshireplanning.org. Accessed on 18 Dec. 2008. 
428 Sustainable Development and Planning XI

[25] Akin, D., Çavuşoğlu, Ö. \& Demircioğlu, E., A Review of the Kadıköy Tramway regarding the quality of urban life with respect to urban rail systems. Quality of Urban Life: Policy versus Practice, ITU, Urban and Environmental Planning Research Centre: Istanbul, pp. 585-595, 2003.

[26] Alonso, W., Urban zero population growth. Journal of the American Academy of Arts and Sciences, 10214, pp. 191-206, 1973.

[27] Hardoy, J.E. \& Satterthwaite, D., Third world city. Urban Studies, 34(5-6), pp. 793823, 1992.

[28] Heidegger, M., Everyday life. Identity and Difference, Harper \& Row: New York, 1969.

[29] Nairn, I., The American Landscape: A Critical View, Random House: New York, 1965. 